\title{
Caring for patients in mental health services during COVID-19 outbreak in China
}

\author{
Ruihua Hou ${ }^{1 *} \mathbb{D}$, Limin Yang ${ }^{2}$, Zhen Tang ${ }^{3}$ and Teng Chen ${ }^{4}$
}

\begin{abstract}
This article reflects on some radical changes made in mental health services in China which include the implementation of the initial triage system and the special isolation ward, the early screening and testing for both patients and staff, the smaller teams working on rotating shifts on-site, and the adequate provision of PPE. These measures would be of great value as a reference to the effective delivery of mental health services in other countries through this pandemic.
\end{abstract}

Keywords: COVID-19, Mental health services, Psychiatry, Isolation, Testing

\section{Background}

The World Health Organization has declared COVID-19 a "public health emergency" [1]. With 173 million people living with mental disorders in China [2], the COVID19 outbreak has posed an emerging challenge for mental health services in China [3].

Following the report of a cluster of 50 cases of COVID19 amongst inpatients in one psychiatric hospital in Wuhan, China, on 9th February, 2020 [4], significant concerns were raised. A statement addressed the prevention and control of COVID-19 in patients with severe mental disorders on 17th February, 2020 [5]. Mental health institutions have since taken a series of mandatory measures to address prevention of nosocomial cross-infection between patients and medical staff during the pandemic period, as well as easing difficulties of access to mental health services.

\section{Main text}

\section{On-site triage}

On-site COVID-19 screening sites have been temporarily set up at entrances of hospitals. This includes using

\footnotetext{
*Correspondence: r.hou@soton.ac.uk

${ }^{1}$ Department of Psychiatry, Clinical and Experimental Sciences, Faculty of Medicine, University of Southampton, Southampton, UK

Full list of author information is available at the end of the article
}

infra-red thermometers to screen for fever in all patients and carers, as well as recording travel and contact histories within known epidemic areas over the past month. Patients are issued with coloured cards to label their potential risk of infection (green indicates low risk; yellow indicates moderate risk; red indicates high risk). Essential personal protective measures are required (such as wearing a mask) at this stage.

\section{Admission pathways}

Hospitals set up special isolation wards for all new admissions to monitor any COVID-19 symptoms due to the incubation period. After 2 weeks of observations, a negative test for COVID-19 is then required before admission to the non-infected general wards. Stricter measures are introduced to geriatric wards including separation from the rest of the hospital to protect the most vulnerable patients. This pathway is outlined in the flowchart in Fig. 1.

\section{Medical staff}

All medical staff have weekly COVID-19 virus nucleic acid tests taken with routine daily monitoring of body temperature. In special isolation wards, the workforce is divided into smaller subunits to limit the transmission of the virus within teams. The team for each isolation ward is divided into two subgroups with each

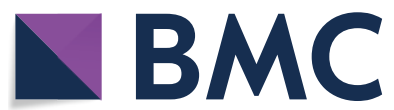

(c) The Author(s) 2020. This article is licensed under a Creative Commons Attribution 4.0 International License, which permits use, sharing, adaptation, distribution and reproduction in any medium or format, as long as you give appropriate credit to the original author(s) and the source, provide a link to the Creative Commons licence, and indicate if changes were made. The images or other third party material in this article are included in the article's Creative Commons licence, unless indicated otherwise in a credit line to the material. If material is not included in the article's Creative Commons licence and your intended use is not permitted by statutory regulation or exceeds the permitted use, you will need to obtain permission directly from the copyright holder. To view a copy of this licence, visit http://creativeco mmons.org/licenses/by/4.0/. The Creative Commons Public Domain Dedication waiver (http://creativecommons.org/publicdomain/ zero/1.0/) applies to the data made available in this article, unless otherwise stated in a credit line to the data. 


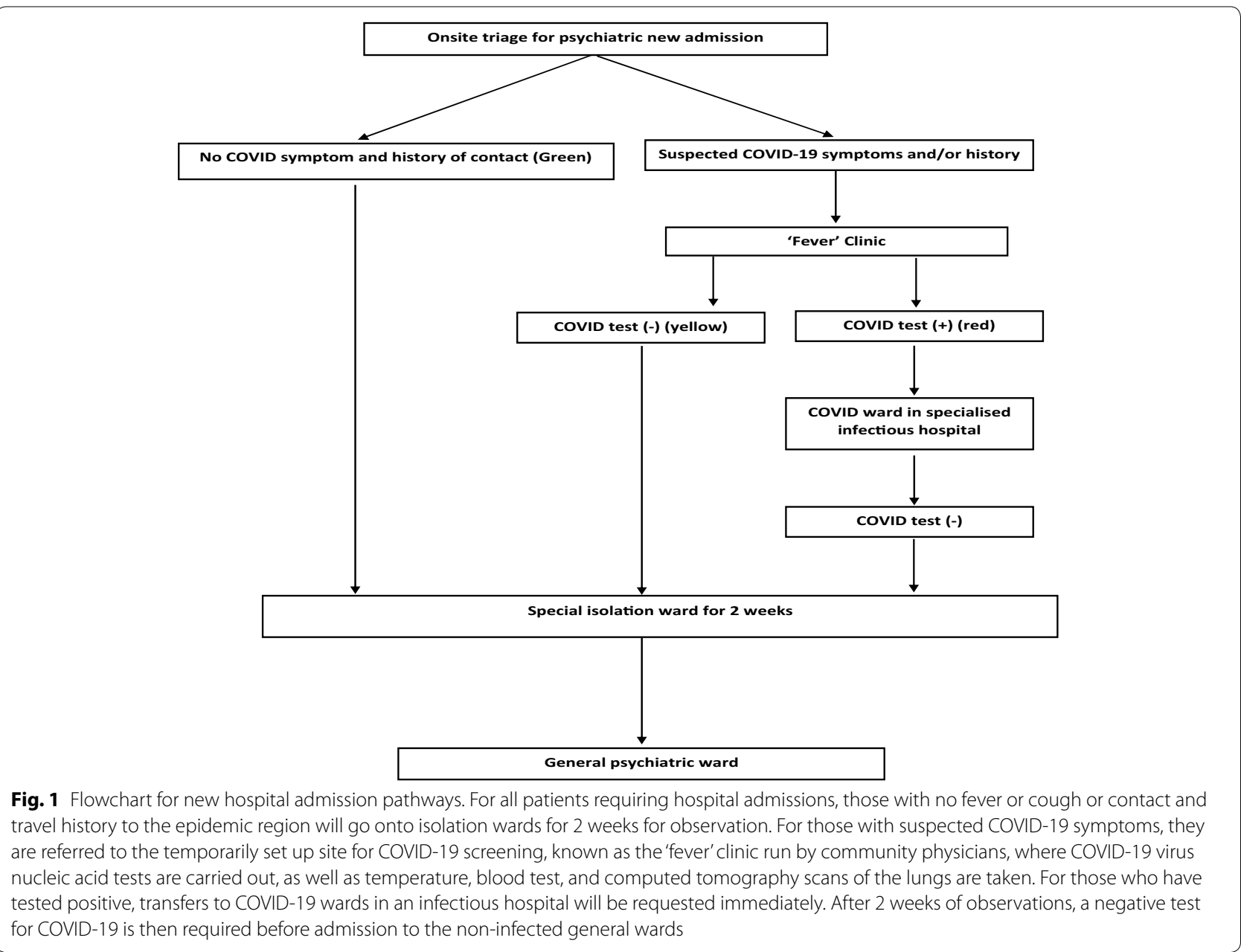

group working alternate fortnights on the ward; this alternating rota of 14 days work followed by 14 days rest is used for all staff working on the special isolation wards across mental health services. During those 14 working days, all medical staff are accommodated onsite in the hospital, followed by self-isolation for 7 days at their own home. All communication plans are delivered via WeChat online.

\section{Personal protective equipment (PPE)}

Appropriate PPE for all psychiatric staff are provided to minimise transmission via droplets as well as via the faecal-oral route. Due to the increased risk in outpatient clinical settings, all psychiatrists and nurses wear PPE including surgical face masks, long-sleeved disposable gowns, disposable gloves, disposable overshoes, and eye protection goggles. Staff working in isolation wards wear surgical face masks or N95 respirators and long-sleeved disposable gowns. Strict deep-cleaning measures were introduced in both wards and outpatient clinics.

\section{Online services}

To limit the number of outpatient visits, a switch of psychiatric care to online services has been made available. $24 / 7$ hotline is offered to promote wellness by focusing on coping strategies using psychoeducation and cognitive behavioural techniques following the principles for emergency psychological crisis intervention for COVID-19 pneumonia epidemic [6]. In addition, telemedicine is offered to patients requiring referral for mental health evaluation and care, along with increased prescription period from 1 month to 2 months. New treatment advice for COVID-19-related psychiatric symptoms are accessible online [7]. This has substantially reduced the patient flow in the outpatient clinical settings. Outpatient clinics remain open to those patients who are unable to access online services, those who need close monitoring of their physical conditions, and those who need urgent care, with stricter protection measures in place in these services including PPE, deep cleaning, body temperature monitoring, and distancing. 


\section{Conclusions}

The key features of the changes to mental health services in China in response to COVID-19 include the implementation of the initial triage system and the isolation ward, the early screening and testing for both patients and staff, the smaller teams working on rotating shifts on-site, and the adequate provision of PPE. As a result of such radical and strict prevention and control measures, the spread of COVID-19 has been contained within the mental health services. However, cases outside of China have been growing rapidly, particularly in the USA and Europe. Under continued spread of COVID-19 worldwide, active and effective measures are critical to ensure the safety, care, and treatment of people affected by mental illness. Measures taken in China should be of great value as a reference to the effective delivery of mental health services in other countries through this pandemic.

\section{Abbreviations}

PPE: Personal protective equipment; COVID-19: Coronavirus Disease 2019.

\section{Acknowledgements}

Not applicable.

\section{Authors' contributions}

$\mathrm{RH}$ developed the initial idea and drafted the manuscript; LY, ZT and TC contributed to the collection of relevant materials. All authors read and approved the final manuscript.

\section{Authors' information}

$\mathrm{RH}$ : As an associate professor of psychiatry working in the UK, I also hold visiting professor positions at university hospitals in China. I have worked closely with colleagues in psychiatric hospitals over the last 10 years. I have been in close correspondence with fellow Chinese psychiatrists to understand what measures have been taken since the outbreak of COVID-19 first started in Wuhan in January.

\section{Funding}

Not applicable.

\section{Availability of data and materials}

Not applicable.

Ethics approval and consent to participate

Not applicable.
Consent for publication

Not applicable.

\section{Competing interests}

The authors declare that they have no competing interests.

\section{Author details}

${ }^{1}$ Department of Psychiatry, Clinical and Experimental Sciences, Faculty of Medicine, University of Southampton, Southampton, UK. ${ }^{2}$ Shandong Mental Health Centre, Jinan, Shandong, China. ${ }^{3}$ Suzhou Guangji Hospital, Suzhou, Jiangsu, China. ${ }^{4}$ Shandong University Qilu Hospital, Jinan, Shandong, China.

Received: 6 August 2020 Accepted: 11 November 2020

Published online: 22 November 2020

\section{References}

1. World Health Organization. Coronavirus disease (COVID-19) pandemic. https://www.who.int/emergencies/diseases/novel-coronavirus-2019. Accessed 23 Mar 2020.

2. Xiang Y-T, Yu X, Sartorius N, Ungvari GS, Chiu HF. Mental health in China: challenges and progress. Lancet. 2012;380:1715-6.

3. Pfefferbaum B, North CS. Mental health and the Covid-19 pandemic. N Engl J Med. 2020. https://doi.org/10.1056/NEJMp2008017.

4. China Newsweek. Collective infections of coronavirus among 50 patients and 30 health workers in one psychiatric hospital in Wuhan. Shanghai Obs. https://www.jfdaily.com/news/detail?id=208584. Accessed 17 Feb 2020.

5. Integrated group of joint prevention and control mechanism for the outbreak of new coronavirus pneumonia of the state council of China. Notice on Strengthening the Treatment and Management of Patients with Severe Mental Disorders during the Outbreak of the New Coronary Pneumonia (in Chinese). http://www.nhc.gov.cn/jkj/s3577/202002/f315a 6bb2955474c8ca0b33b0c356a32.shtml. Accessed 18 Feb 2020

6. National Health Commission of China. Principles for Emergency Psychological Crisis Intervention for COVID-19 Pneumonia Epidemic (in Chinese). http://www.nhc.gov.cn/jkj/s3577/202001/6adc08b96659425 3b2b791be5c3b9467.shtml. Accessed 17 Feb 2020.

7. Si T, Wang G. Drug treatment of new coronary pneumonia-related psychiatric symptoms (expert advice). https://mp.weixin.qq.com/s/Q7r-Wp7PY 554qxL9sXnDFA. Accessed Feb 2020.

\section{Publisher's Note}

Springer Nature remains neutral with regard to jurisdictional claims in published maps and institutional affiliations.

\footnotetext{
Ready to submit your research? Choose BMC and benefit from:

- fast, convenient online submission

- thorough peer review by experienced researchers in your field

- rapid publication on acceptance

- support for research data, including large and complex data types

- gold Open Access which fosters wider collaboration and increased citations

- maximum visibility for your research: over $100 \mathrm{M}$ website views per year
}

At BMC, research is always in progress.

Learn more biomedcentral.com/submissions 